\title{
The relationship between China-South Pacific island countries tourism and trade in the context of the Belt and Road Initiative
}

\section{Fang Ye}

China (Zhejiang) Free Trade Experimental Zone Research Institute, Zhejiang Ocean University, China

Yelu0930@।63.com (corresponding author)

Jaepil Park

National Institute of International Entrepreneurship, Kunsan University, South Korea ippark@kunsan.ac.kr

\section{ChunLin Li}

School of economics and management, Zhejiang Ocean University, China |3454068887@|63.com

\section{Yixiong $\mathrm{He}$}

School of economics and management, Zhejiang Ocean University, China heyixiongmail@163.com

\begin{abstract}
In the context of the Belt \& Road Initiative (BRI), China attaches great importance to tourism diplomacy with the South Pacific Island Countries (SPIC). The study of the relationship between tourism and trade is therefore of great significance for the further development of bilateral political and economic cooperation. This paper selected data on the inbound and outbound tourism, as well as import and export trade, between China and SPIC in the period 1998-2017, and used econometric methods to demonstrate the interconnections. The results show that there is a positive long-term equilibrium relationship between passenger flow and import and export trade of China and SPIC. Under the influence of policies, the interaction between inbound and outbound tourism and import and export trade is characterized by periodic fluctuations. China's outbound tourism to SPIC plays a stronger role to import trade than to export trade. From the analysis of two sections, major events have a moderating effect on the proportion of SPIC tourists and trade dependence on SPIC, while both of the proportion of Chinese tourists and their trade dependence on China are on the rise, and these two have a pulling effect for each other.
\end{abstract}

Keywords: Belt and Road Initiative (BRI), China, co-integration, tourism, international trade, Pacific Island Countries, $21^{\text {st }}$-Century Maritime Silk Road

https://doi.org/10.24043/isj.126 • Received September 2019, accepted September 2020

(C) 2020-Institute of Island Studies, University of Prince Edward Island, Canada. 


\section{Introduction}

The South Pacific Island Countries (hereafter, 'SPIC') are an extension of the $21^{\text {st }}$-Century Maritime Silk Road, which is itself part of China's Belt and Road Initiative (BRI), and are an important part of China's activities aimed at developing the Asia-Pacific economy (Ye \& $\mathrm{Wu}, 2016)$. As the BRI gradually benefits island countries along its route, especially in recent years, China and the Pacific island countries have signed BRI memoranda of understanding to achieve cooperation in the development of island tourism and agricultural products.

China has great influence in the South Pacific region. China and South Pacific island countries have entered a new era of strategic partnership development (Xu, 2018). Bilateral trade volume grew from $\$ 4.512$ billion in 2012 to $\$ 8.66$ billion in 2018 , with an average annual growth rate of $11.48 \%$. In parallel, the number of inbound and outbound tourists has also increased on a yearly basis. The number of tourists from China to SPIC has increased from 55, 000 in 2012 to 143, 000 in 2017 and 224, 900 in 2018, with an average annual growth rate of $14.64 \%$, with the result that Chinese tourists have become crucial to the sustainable development of tourism in the South Pacific (Shie, 2007; Cheer, Pratt, \& Tolkach, 2018). The simultaneous development of bilateral international trade and inbound and outbound tourism indicates a certain correlation, at least when it comes to China and SPIC. It is thus important to ask: How tourism and trade relate to each other? How strong is the intensity of this interaction? For how long will this mutual impact last? Researching these issues is of great theoretical and practical significance for promoting the positive interaction between tourism and trade between China and SPIC.

Research on the relationship between international trade and international tourism has increased since around 2000. Kulendran and Wilson (2002) pioneered the 'Marco Polo Hypothesis' and the 'Interests and Concerns' for tourism and trade, which were subsequently answered and verified by scholars. Current research is developing along three main trajectories. The first is basic theoretical research into tourism and trade. Tourism is an important tool for trade development, and trade in services is also an important way of promoting economic growth (Hazari \& Sgro, 2004). Tourism and trade have an interactive relationship. Based on this interaction mechanism, a three-stage model has been constructed, whereby tourism triggers trade, trade promotes tourism, and preference capacity is limited (Sun \& Zhou, 2012; Wang, 2012). Interactions between tourism and trade can be divided into three types: tourism promotes trade, trade promotes tourism, and a mixed type (Shi, Zhou, \& Shen, 2015).

The second research direction uses various measurement methods to demonstrate the relationship between tourism and trade. The VAR (Vector AutoRegression) model has been used to study Granger causality between international travel and international trade in China (Shan \& Wilson, 2010). A dynamic, heterogeneous panel data technology has been used to analyze long-term and short-term relationships between international tourism and trade in OECD countries (Santana-Gallego, Ledesma-Rodríguez, \& Pérez-Rodríguez, 2011). The gravitational model has been used to study bilateral trade and tourism relations between the EU and the Black Sea OECD countries, and the international tourism demand has been argued to promote the development of bilateral service trade (Sisko \& Darvidou, 2019). The co-integration test explores the relationship between trade and tourism within small island states. There is a long-term, two-way relationship between small island tourism and trade, while short-term linkages are mainly characterized by tourism playing a leading role in trade. 
The third research direction investigates the relationship between tourism, trade, and other influencing factors. Along these lines, the co-integration boundary test and the Granger causality test have been used to study the long-term equilibrium relationship between tourism, trade, and real income growth in Cyprus (Katircioglu, 2011; Massidda \& Mattana, 2013). A wavelet analysis of US trade, economic growth, and international tourism has been performed for the period 1999-2018, finding that increased trade leads to increased tourist traffic, that tourist spending grows faster than economic growth, and that tourism drives economic growth (Kumar, Prashar, \& Jana, 2019). Based on panel data of tourism and trade between China and 24 target countries from 1995 to 2016, another study used the threshold regression and the coupling coordination model to explore the threshold effect and country differences of import and export trade on entry and exit tourism under different income levels (Chen \& Cheng, 2018). Traffic is an important factor affecting tourism. Some scholars have built a transportation service-international tourism-goods trade $(3 \mathrm{t})$ interactive relationship, which confirms that transportation is the foundation for interconnection. On this basis, tourism and trade mutually promote each other (Ma \& Sun, 2019).

In general, a considerable number of studies have been performed on the interaction between tourism and trade, obtaining interesting results. These studies have mostly used traditional linear regression, descriptive statistics, and correlation analysis to prove the relationship between tourism and trade. However, these methods cannot reveal in detail the mechanisms and the intensity of the interaction between these two elements (Rasheed et al, 2019) and cannot identify the differences and the correlation between tourism and trade in different countries at different times. Most studies use cross-sectional data, lacking consideration of continuity of variables. Moreover, they focus mainly on the interaction between inbound and outbound tourism and trade in a single country or region and do not consider the interaction between tourism and trade between two countries or regions.

In order to address this gap in the research, the present paper comprehensively uses time series processing techniques such as the ADF (Augmented Dickey-Fuller) test, the cointegration test, Granger causality test, and build regression equation to empirically study the interaction between import and export trade and inbound tourism between China and SPIC in the period 1998-2017. Moreover, this paper analyzes the correlation with tourism interaction and trade dependence. The paper is intended to reveal and explain the mechanism and dynamic characteristics of import and export trade and inbound and outbound tourism.

\section{Overview of the study area}

The SPIC are veritable pocket countries located in the South Pacific region. SPIC include the Cook Islands; Federated States of Micronesia, Fiji, Kiribati, Marshall Islands, Nauru, Niue, Palau, Papua New Guinea, Samoa, Solomon Islands, Tonga, Tuvalu, and Vanuatu (the 14 Pacific Islands Forum countries). In 2018 figures, they have a total land area of just 550, 000 $\mathrm{km}^{2}$ and a total population of 11, 116, 500. Among them, Papua New Guinea is the largest is area $\left(452,800 \mathrm{~km}^{2}\right)$ and population (8.6 million). The smallest country, Nauru, has a land area of only $21 \mathrm{~km}^{2}$ and a population of about 12, 700. SPIC are characterized by beautiful natural environments and unique tourism resources. The natural beauty of the sea and the unique tropical style attract tourists from around the world, making the tourism industry flourish. In 2018, the number of inbound visitors to SPIC reached 2.23 million, of which 
124, 900 were Chinese tourists. In 2017, the proportion of Chinese tourists within the total number of inbound tourists to different SPIC countries ranged from $0.3 \%$ in New Caledonia to $47.0 \%$ in Palau, with an average of $7.3 \%$ (Cheer, Pratt, \& Tolkach, 2018). Tourism plays a vital role in SPIC (Narayan, 2010), with trade services accounting for more than $45 \%$ of total trade in some countries (Narayan, Sharma, \& Bannigidadmath, 2013). China and SPIC are developing solid relations in the context of the BRI. SPIC have signed BRI bilateral cooperation documents with China in order to benefit from China's rapid economic growth, and in 2018, the trade volume between China and SPIC reached US\$8.66 billion.

\section{Variable design and data sources}

\section{Research variables}

(1) Entry and exit passenger traffic. This is the main statistical indicator to measure bilateral tourism. Accordingly, this paper used the Outbound Tourists from China to SPIC (OTCS), and the Inbound Tourists from SPIC to China (ITSC), as shown in Table 1.

(2) Import and export trade volume. These are the main economic indicators of international trade, and the basis of the international trade system. The variables selected in this paper are: the Value of Imports and Exports from China to SPIC (IE), the Value of Exports from China to SPIC (VECS), the Value of Imports from the China to SPIC (VICS) (VICS), the Value of Exports from SPIC to China (VESC), and the Value of Imports from SPIC to China (VISC), as shown in Table 1.

(3) Tourism interaction and trade dependence. This indicator focuses on the two-way relationship between tourism and trade. It includes both China to SPIC and SPIC to China. This paper uses tourism proportion and trade dependence to characterize.

In this paper, the proportion of China's outbound SPIC traffic within SPIC inbound traffic and the proportion of SPIC inbound Chinese traffic within China inbound traffic are used to reflect the two-way tourism interactions. The linkage relationship (that is, the trade dependence between China and SPIC) is shown in Table 1. As an environmentally sensitive industry, tourism is extremely vulnerable to various emergencies such as political, economic, and natural disasters at home and abroad. Therefore, we have accounted for the moderating effects of bilateral economic forums, the opening of flights, simplification of tourist visas, and adjustment of tariff policies on the proportion of tourism and trade dependence.

\section{Data sources}

This paper selected China's import and export trade with SPIC and the number of inbound and outbound tourists to explore the interactive relationship between trade and tourism. The main data comes from the China Statistical Yearbook, the SPTO (South Pacific Tourism Organization), the World Bank database, and the Tourism Statistics Yearbook of the World Tourism Organization. Due to the large differences in the levels of economic development and degrees of openness among countries, the times of import and export trade and the statistics caliber of inbound and outbound tourism are not the same. Given data availability, this paper took the year 1998 as the starting point for research. In order to avoid violent fluctuations caused by different data units, the possible heteroscedasticity was eliminated. In order to ensure that the time series follow a stationary sequence, a natural logarithmic 
transformation was performed for the number of tourists entering and leaving China, the import trade, the export trade, and the total import and export trade data.

Table 1. Data sources, description, and variable processing method.

\begin{tabular}{|c|c|c|c|}
\hline Index & $\begin{array}{l}\text { Rep. } \\
\text { symbol }\end{array}$ & Data sources & Variables processing method \\
\hline $\begin{array}{l}\text { Value of imports and exports } \\
\text { from China to SPIC }\end{array}$ & IE & $\begin{array}{l}\text { China Statistical } \\
\text { Yearbook }\end{array}$ & \multirow{5}{*}{$\begin{array}{l}\text { China's dependence on SPIC } \\
\text { trade (CTS) = China-SPIC } \\
\text { import and export trade volume } \\
\text { / China GDP } \\
\text { SPIC's dependence on China's } \\
\text { trade (STC) = China-SPIC } \\
\text { import and export trade volume } \\
\text { / SPIC GDP }\end{array}$} \\
\hline $\begin{array}{l}\text { Value of imports from China } \\
\text { to SPIC }\end{array}$ & VICS & $\begin{array}{l}\text { China Statistical } \\
\text { Yearbook }\end{array}$ & \\
\hline $\begin{array}{l}\text { Value of exports from China } \\
\text { to SPIC }\end{array}$ & VECS & $\begin{array}{l}\text { China Statistical } \\
\text { Yearbook }\end{array}$ & \\
\hline $\begin{array}{l}\text { Value of exports from SPIC } \\
\text { to China }\end{array}$ & VESC & $\begin{array}{l}\text { China Statistical } \\
\text { Yearbook }\end{array}$ & \\
\hline $\begin{array}{l}\text { Value of imports from SPIC } \\
\text { to China }\end{array}$ & VISC & $\begin{array}{l}\text { China Statistical } \\
\text { Yearbook }\end{array}$ & \\
\hline $\begin{array}{l}\text { China's outbound SPIC } \\
\text { traffic }\end{array}$ & OTCS & SPTO, World Bank & \multirow{4}{*}{$\begin{array}{l}\text { China's outbound travel ratio } \\
\text { (CSIT) = China's outbound } \\
\text { SPIC traffic / SPIC inbound } \\
\text { traffic } \\
\text { SPIC inbound tourism ratio } \\
\text { (SCIT) = SPIC inbound Chinese } \\
\text { traffic / China inbound traffic }\end{array}$} \\
\hline $\begin{array}{l}\text { Chinese outbound passenger } \\
\text { traffic }\end{array}$ & CIT & $\begin{array}{l}\text { China Statistical } \\
\text { Yearbook }\end{array}$ & \\
\hline SPIC inbound Chinese traffic & ITSC & $\begin{array}{l}\text { China Statistical } \\
\text { Yearbook }\end{array}$ & \\
\hline SPIC inbound traffic & SIT & SPTO. World Bank & \\
\hline
\end{tabular}

Notes regarding Table 1: 1. Data for China does not include Taiwan, Hong Kong, and Macau. 2. The South Pacific Tourism Organization (SPTO) did not list China's inbound tourists before 2009 but placed this figure in the 'East Asia and Pacific' category. For the number of Chinese Inbound Tourists from 1998 to 2008, this study takes 2009 as the starting point and calculates the number of Chinese Inbound Tourists to South Pacific island countries from 2008 to 1998 according to the annual growth rate of 'East Asia and the Pacific'.

\section{Analysis of the relationship between China and SPIC inbound and outbound passenger flow and import and export trade}

\section{Stationarity test of variables}

In order to avoid pseudo-regression, the unit root test must be performed on each data sequence before doing a time series analysis, to investigate the stationarity of the time series. If the time series is non-stationary, then the variables should be differential before being used in the linear regression model. In this paper, the Eviews 8.0 software was used to test the stationarity of $\operatorname{lnITSC}$, lnOTCS, lnVECS, lnVICS, and lnIE by using the ADF test method. The optimal lag order was determined by using the SC (Schwarz Criterion).

The test results (Table 2) show that the ADF values of lnITSC, lnOTCS, lnVECS, lnVISC, and lnIECS are greater than the critical value at a confidence level of $5 \%$. Hence, each variable accepts the null hypothesis, and the level values of the five variables and all the first-order difference values contain unit roots and are non-stationary sequences. The ADF values of the 
first-order difference values of lnITSC, lnOTCS, lnVECS, lnVISC, and lnIECS are lower than the critical value at $5 \%$ confidence level. Hence, all variables reject the null hypothesis, and are first-order and single-order sequences, which can be used in the next co-integration test.

Table 2: Test results of the ADF values of all variables.

\begin{tabular}{|c|c|c|c|c|c|}
\hline Variable & $\begin{array}{l}\text { Inspection } \\
\text { type }\end{array}$ & ADF value & $5 \%$ threshold & $\begin{array}{l}\text { Corresponding } \mathrm{p} \\
\text { value }\end{array}$ & Conclusion \\
\hline$\overline{\operatorname{lnITSC}}$ & $\overline{(\mathrm{C}, 0,0)}$ & 2.154 & -3.030 & 0.228 & Unstable \\
\hline$\triangle \operatorname{lnITSC}$ & $(\mathrm{C}, \mathrm{T}, 1)$ & -4.007 & -3.829 & 0.038 & Smooth \\
\hline $\operatorname{lnOTCS}$ & $(0,0,0)$ & 2.500 & -1.960 & 0.995 & Unstable \\
\hline$\triangle \operatorname{lnOTCS}$ & $(0,0,0)$ & -2.049 & -1.961 & 0.042 & Smooth \\
\hline $\operatorname{lnVECS}$ & $(0, \mathrm{~T}, 0)$ & 3.285 & -1.960 & 0.999 & Unstable \\
\hline$\triangle \ln V E C S$ & $(\mathrm{C}, \mathrm{T}, 0)$ & -3.429 & -3.040 & 0.024 & Smooth \\
\hline $\operatorname{lnVICS}$ & $(\mathrm{C}, \mathrm{T}, 0)$ & -2.127 & -3.030 & 0.237 & Unstable \\
\hline$\triangle \operatorname{lnVICS}$ & $(\mathrm{C}, \mathrm{T}, 1)$ & -7.342 & -3.052 & 0.000 & Smooth \\
\hline $\ln I E$ & $(\mathrm{C}, \mathrm{T}, 0)$ & -2.200 & -3.030 & 0.212 & Unstable \\
\hline$\triangle \ln I E$ & $(\mathrm{C}, 0,0)$ & -4.213 & -3.040 & 0.005 & Smooth \\
\hline
\end{tabular}

Co-integration test of variables

In order to further explore whether there is a long-term stable relationship between the import and export passenger flow and the import trade, export trade, and import and export trade variables, it was necessary to conduct a co-integration test on the sequence. This paper used the E-G(Engel-Granger) two-step method to test whether a long-term co-integration relationship exists between the variables.

First, using the least squares estimation method, lnITSC were set as dependent variables, and lnVESC, lnVISC, and lnIE were set as independent variables; lnOTCS were set as dependent variables, and lnVECS, lnVICS, and lnIE as independent variables, to establish the following regression equations. The following regression equations were estimated to be obtained:

$$
\begin{aligned}
& \ln I \mathrm{TSC}_{\mathrm{t}}=8.331+0.069 \ln V E S C_{t}+0.237 \ln V I S C_{t}-0.200 \ln I E_{t}+\varepsilon_{\mathrm{t}} \\
& \ln O \mathrm{TCS}_{\mathrm{c}}=6.658+0.356 \ln V E C S_{\mathrm{c}}+0.779 \ln V I C S_{\mathrm{c}}-0.726 \ln I E_{\mathrm{c}}+\varepsilon_{\mathrm{c}}
\end{aligned}
$$

The ADF test was performed on the estimated residual sequences $\varepsilon_{\mathrm{t}}$ and $\varepsilon_{\mathrm{c}}$, and the test results are shown in Table 3.

Table 3: Residual unit root test.

\begin{tabular}{lllllll}
\hline Variable & $\begin{array}{l}10 \% \text { critical } \\
\text { level }\end{array}$ & $\begin{array}{l}5 \% \text { critical } \\
\text { level }\end{array}$ & $\begin{array}{l}1 \% \text { critical } \\
\text { level }\end{array}$ & ADF value & p value & Conclusion \\
\hline$\varepsilon_{\mathrm{t}}$ & -1.607 & -1.6961 & -2.700 & -4.288 & 0.000 & Smooth \\
$\varepsilon_{\mathrm{c}}$ & -1.606 & -1.964 & -2.718 & -2.356 & 0.022 & Smooth \\
\hline
\end{tabular}


According to the above analysis, there is a long-term co-integration relationship between $\operatorname{lnITSC}$, lnVESC, lnVISC, lnIE, and lnOTCS, lnVECS, lnVICS, lnIE, although there may be short-term fluctuations. Therefore, in order to improve the accuracy of the model, this paper established an error correction model to analyze the relationship between the variables in the short term.

The regression equations, established using Eviews 8.0 for the least squares estimation of the error correction model, are as follows:

$$
\begin{aligned}
& \triangle \operatorname{lnITSC}_{\mathrm{t}}=-0.006-0.732 \mathrm{ecm}_{\mathrm{t}-1}+0.181 \triangle \operatorname{lnVESC}_{t}+0.210 \triangle \operatorname{lnVISC}_{t}-0.254 \operatorname{lnIE} \mathrm{IE}_{t}+\varepsilon_{\mathrm{t}} \\
& \triangle \operatorname{lnOTCS}_{\mathrm{c}}=0.083-0.033 \mathrm{ecm}_{\mathrm{c}-1}+0.088 \triangle \operatorname{lnVECS}_{\mathrm{c}}+0.086 \triangle \operatorname{lnVICS}_{\mathrm{c}}-0.158 \operatorname{lnIE}_{\mathrm{c}}+\varepsilon_{\mathrm{c}}
\end{aligned}
$$

As shown in the formulas presented, the coefficient of the error correction term is negative, which is consistent with the principle of the inverse correction mechanism. The magnitude of the error correction term coefficient reflects the adjustment strength of the short-term deviation from the long-term equilibrium. The coefficients are equal to -0.732 and -0.033 respectively, indicating short-term fluctuations. When deviating from the longterm equilibrium, the unbalanced state will be pulled to the equilibrium state with an adjustment strength of 0.732 and 0.033 respectively. This indicates that there is a long-term equilibrium relationship between China and SPIC in terms of inbound and outbound tourism, import trade, export trade, and import and export trade.

\section{Granger causality test}

Co-integration analysis indicates that there is a long-term stable equilibrium relationship and a short-term dynamic adjustment mechanism in the inbound and outbound tourism and bilateral trade between China and SPIC, but it is uncertain whether there is a causal relationship between them. Therefore, this paper uses the Granger test to explore the causal interaction between tourism and trade (see Table 4).

The results show that, at $10 \%$ significance level, China's tourists outbound to SPIC is a one-way Granger causality test of China's import trade volume from SPIC. That is, outbound tourism can promote import trade. With the implementation of Belt and Road Initiative and the policy effects of the China-South Pacific Island Countries Economic Development and Cooperation Forum, the number of China's outbound tourism and business visits increases, and the resources (such as fishery products, forest products, minerals, and energy resources) imported from SPIC increase as well, raising the export trade volume of SPIC. Especially following Chinese President Xi Jinping's visit to Pacific island countries and the opening of direct flights, outbound tourism and import trade volume have grown rapidly. China's outbound tourism to SPIC in 2014 increased by $27 \%$ compared to 2013, much higher than the average annual growth rate (10.5\%) in the period of 1998-2017. During the same period, the import trade volume of China from SPIC in 2014 increased by $56.75 \%$ compared to 2013, far above the average annual growth rate (32.79\%) in the period of 1998-2017, indicating that outbound tourism has a significant positive effect on import trade.

At 10\% significance level, China's export trade volume to SPIC is a one-way Granger causality test of China's tourists outbound to SPIC, meaning that export trade promotes outbound tourism. This is because China is a country with trade surplus to SPIC. That is to 
say, the trade volume that China exports to SPIC exceeds the trade volume that China imports from SPIC. In the period of 1998-2017, there is asymmetry in the import and export trade between the two parties. China's trade surplus with SPIC expanded from US $\$ 0.002$ billion in 1998 to US $\$ 2.875$ billion in 2016 (China is a deficit country in 1999-2005), but this status gradually reversed: the trade balance decreased to US $\$ 1.231$ billion in 2017 and then transferred from surplus country to deficit country in 2018. In general, the average annual growth rate of China's export trade volume with SPIC (33.09\%) in 1998-2017 is higher than the average annual growth rate of China's tourists outbound to SPIC $(10.5 \%)$, indicating that the development of export trade is faster than that of outbound tourism to SPIC. From the perspective of SPIC, China's high-quality and inexpensive products have attracted residents in Pacific island countries. China mainly exports mechanical and electrical products, clothing and textiles, light industrial products, and chemical and medical raw materials to SPIC. The broad market of SPIC has also attracted China business travelers, triggering outbound tourism to SPIC. However, since the effect of commodity externalities requires a certain period (Li, Chen, \& Liu, 2017), the influence of export trade on outbound tourism has a hysteresis quality under the impact of geographical distance between China and SPIC.

Table 4. Granger causality test results.

\begin{tabular}{|l|l|l|l|l|}
\hline \multirow{2}{*}{ Null Hypothesis } & Obs & $\begin{array}{l}\text { F- } \\
\text { Statistic }\end{array}$ & Prob. & Conclusion \\
\hline VICS does not Granger Cause OTCS & \multirow{2}{*}{17} & 0.675 & 0.528 & Accept \\
\cline { 4 - 6 } OTCS does not Granger Cause VICS & & 0.394 & $0.053^{\star}$ & Reject \\
\hline VECS does not Granger Cause OTCS & \multirow{2}{*}{18} & 2.995 & $0.085^{\star}$ & Reject \\
\hline OTCS does not Granger Cause VECS & & 0.371 & 0.697 & Accept \\
\hline VESC does not Granger Cause ITSC & \multirow{2}{*}{17} & 0.653 & 0.538 & Accept \\
\hline ITSC does not Granger Cause VESC & & 1.222 & 0.329 & Accept \\
\hline VISC does not Granger Cause ITSC & \multirow{2}{*}{17} & 0.030 & 0.970 & Accept \\
\hline ITSC does not Granger Cause VISC & & 0.797 & 0.473 & Accept \\
\hline
\end{tabular}

\section{Periodical characteristics and promoting effect on inbound and outbound tourists and import and export trade}

The relationship of China's tourists outbound to SPIC and bilateral trade

From 1998 to 2017, the number of Chinese tourists outbound to SPIC increased from 26, 400 to 140,200 , with an average annual growth rate of $10.5 \%$. China's import trade volume from SPIC increased from US $\$ 42$ million to US $\$ 3.494$ billion. China's export trade to SPIC increased from US $\$ 45$ million to US $\$ 5.453$ billion, and then fell to US $\$ 4.726$ billion in 2017 , due to the international economic downturn and the sluggish recovery of island countries (Yin et al, 2019). However, the overall rise and fall of outbound tourism and import and export trade have been synchronized. A curve diagram with relevant data can be used to quantitatively reflect the growth trend between the two as follows (Figures $1 \& 2$ ). The intensity of the interaction between the two is reflected by the regression equation. 


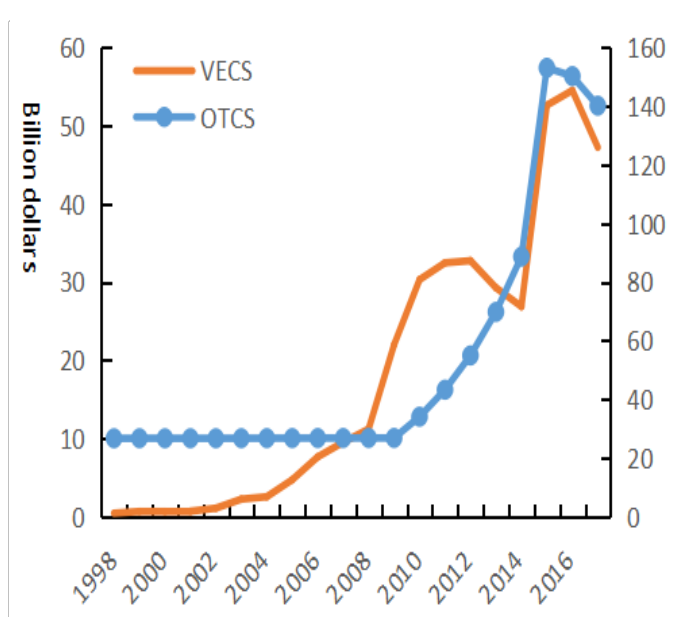

Figure 1. OTCS 和 VECS

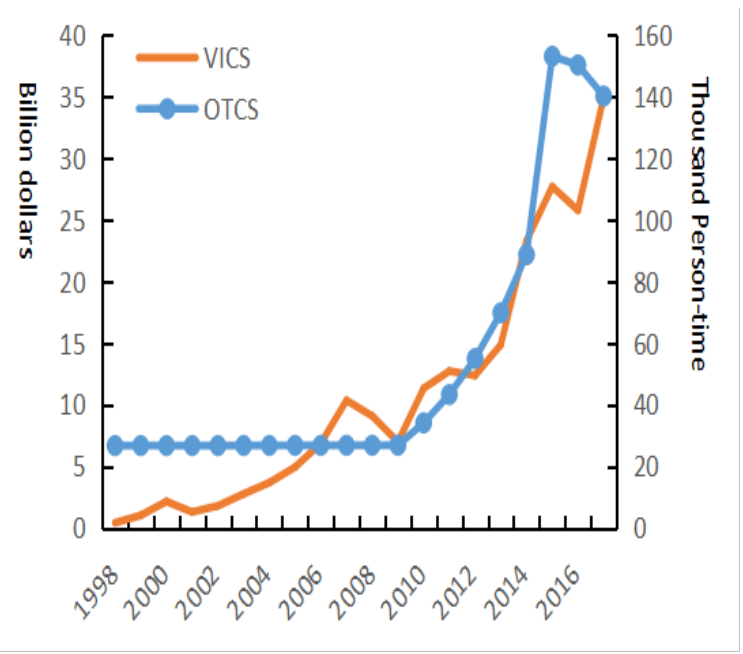

Figure 2. OTCS 和 VICS

(1) China's tourists outbound to SPIC (OTCS) and export trade (VECS) relation. The outbound tourists are greatly affected by transportation policy and the Belt and Road Initiative, while the export trade is obviously affected by changes in customs duties and trade policy. On the basis of Figure 1, outbound tourism and export trade have generally shown a simultaneous growth trend over the past 20 years, which can be roughly divided into three stages. In the first stage, from 1998 to 2007, China's tourists outbound to SPIC and the export trade increased slowly and at a low level. In this stage, there are few countries that have established diplomatic relations with China. In the second stage, from 2007 to 2012, outbound tourists and export trade grew rapidly, which benefited from the first China-South Pacific Island Countries Economic Development and Cooperation Forum in Fiji in April 2006. At this forum, China introduced a number of cooperation measures, leading to a gradual rise in investment and importation of goods from China since 2007. In the third stage, from 2013 to 2017, the overall outbound tourists and export trade showed a development trend with fluctuating adjustment. This was mainly due to the increased number of direct flights from China to South Pacific island countries in 2014 and the signing of the BRI memoranda of understanding Initiative between China and SPIC countries, which promoted the development of China's tourism market outbound to SPIC as well as drove the growth of export trade and China's direct investment in South Pacific island countries, which increased from US $\$ 900$ million in 2013 to US $\$ 4.53$ billion in 2018. During this period, there have been fluctuations in segments, in which the outbound tourists and export trade in 2013-2015 showed simultaneous growth, and tourism and trade achieved a feedback loop. But in 20162017, due to sluggish foreign demand and the weak economic recovery of island countries, both the number of outbound tourists and export trade dropped sharply, by $6.7 \%$ and $13.3 \%$ respectively. This paper uses the data from 1998-2017 to perform a regression analysis on the driving function of outbound tourists on export trade. The driving equation is as follows:

$$
\ln V \mathrm{ECS}=0.877 \times \ln O \mathrm{TCS}+2.903
$$


In the equation, Adjusted $\mathrm{R}^{2}=0.756$, and the marginal elastic coefficient is 0.877 . That is, $1 \%$ growth of tourists volume outbound to SPIC will lead to $0.877 \%$ increase in the export trade volume from China to SPIC, suggesting a positive correlation between the two.

(2) The relationship between China's tourists outbound to SPIC (OTCS) and import trade (VICS). Figure 2 shows that business activities in economic cooperation are closely related to outbound tourism, and outbound tourism and import trade have generally shown fluctuating growth in the long-term sequence. There are roughly three stages. In the first stage, 19982007, outbound tourism and import trade increased simultaneously, but the increase rate of outbound tourism was relatively smaller, from 26, 734 in 1998 to 26, 834 in 2007. The increase rate of import trade was greater, from US $\$ 45$ million in 1998 to US $\$ 1.121$ billion in 2008. The second stage is 2008-2015, under the influence of the financial crisis: the import trades in 2008 and 2009 show sharp decreases (with drops of $12.24 \%$ and $23.25 \%$ respectively), and then outbound tourism and import trade both developed rapidly. Outbound tourism increased by an average annual growth rate of $25.96 \%$ from 26, 844 in 2008 to 153,119 in 2015 , and the import trade increased by an average annual growth rate of $16.54 \%$ from US $\$ 0.909$ billion to US $\$ 2.771$ billion. In particular, the trade effects brought about by the convening of the second bilateral economic forum in 2013, the political effects of the visit of Chinese President Xi Jinping in 2014, and the transportation convenience by the opening of direct flights have greatly increased the number of Chinese tourists traveling to SPIC, thereby promoting import trade. In the third stage, 2016-2017, the number of outbound tourists declined due to sluggish global external demand and the weak economic recovery of island countries, but the import trade showed an upward trend. At this stage, bilateral trade was in an adjustment-oriented development, and the diversified policy dividends promoted outbound tourism, but the stimulating effect on import trade was lagging. This article applies the data in 1998-2017 to perform a regression analysis on the number of outbound tourists and its stimulating effect on import trade. The driving equation is as follows:

$$
\ln \mathrm{VICS}=0.924 \times \ln O T C S+3.240
$$

In the formula: Adjusted $\mathrm{R}^{2}=0.846$, and the marginal elastic coefficient is 0.924 . That is to say, $1 \%$ growth of China's tourists volume outbound to SPIC will lead to $0.924 \%$ increase of China import trade volume from SPIC, suggesting a positive correlation between the two.

(3) The relationship between China's outbound tourists to SPIC (OTCS) and total bilateral trade volume (IE). This paper advances the following hypotheses, drawing upon the research results of Zhao et al. (2011) and others: investigation activities in the visiting of business travelers (official and business activities facilitated by assistance) and trade negotiations (bilateral economic cooperation forums) promote the sale of goods or purchasing results. They trigger import and export trade after coming together and then expand business investigations to sightseeing, vacations, and other forms of tourism. The business tourism activities that fall under assistance and negotiation activities between China and SPIC are among the typical examples of promoting trade. The driving equation of China's outbound tourism to SPIC on the import and export trade is constructed through data simulation as follows:

$$
\ln I E=0.912 \times \ln O T C S+1.587
$$


In the formula: Adjusted $\mathrm{R}^{2}=0.822$, and the marginal elastic coefficient is 0.912 . That is to say, $1 \%$ growth of China's tourists volume outbound to SPIC will lead to $0.912 \%$ increase of bilateral trade volume, suggesting a positive correlation between the two.

It can be seen from equations (5)-(7) and Figures $1 \& 2$ that, from 1998 to 2017, China's outbound tourists and import and export trade experienced three stages of slow development, rapid development, and adjustment development. In the early stage, affected by factors such as the short time for establishing diplomatic relations, inconvenient transportation, and lack of cooperation and exchanges, China's tourists outbound to SPIC grew slowly, and its driving effect on trade was weak. With the implementation of bilateral economic and trade cooperation and the Belt and Road Initiative to promote bilateral openness, business tourists and trade volume have increased simultaneously, showing a strong two-way interactive relationship. Comparing regression equations (1) and (2), the driving effect or promoting effect of China's tourists outbound to SPIC on trade suggests that the driving effect of import trade is stronger than that of export trade.

\section{The relationship between tourists inbound from SPIC and bilateral trade}

From 1998 to 2017, the import and export trade between SPIC and China and the number of inbound tourists both increased significantly. Inbound tourists increased from 8, 400 in 1998 to 14,200 in 2017, the export trade volume of SPIC to China increased from US $\$ 42$ million to US $\$ 3.494$ billion, and the import trade volume of SPIC from China increased from US $\$ 0.045$ billion to US $\$ 5.453$ billion, which dropped to US $\$ 4.725$ billion due to the international economic downturn and the weak recovery of island countries. The following two curves quantitatively reflects the influence of the inbound tourists from SPIC on bilateral import and export trade and its changing trend (Figures $3 \& 4$ ). The regression equation reflects the intensity of the interaction between the two.

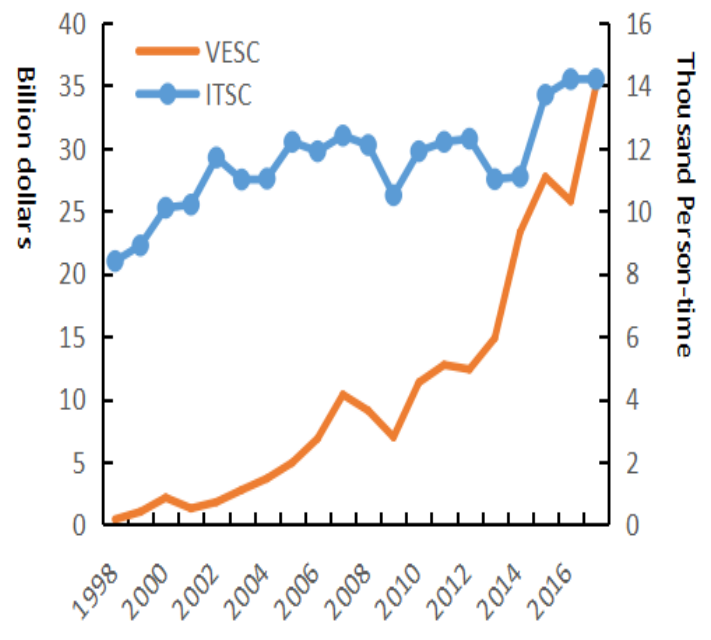

Figure 3. ITSC 和 VESC

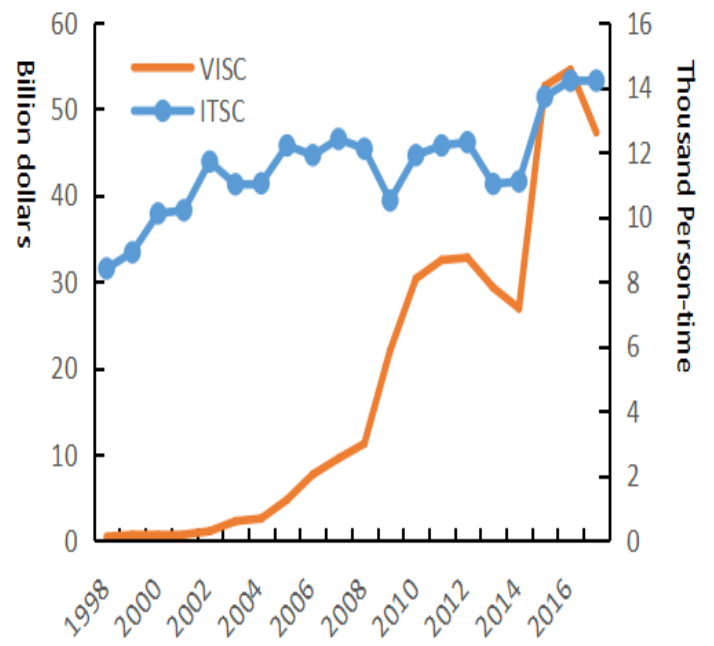

Figure 4. ITSC 和 VISC

(1) The relationship between China's tourists inbound from SPIC (ITSC) and export trade (VESC). Figure 3 shows that the tourists inbound from SPIC and export trade have generally grown in fluctuation under various factors. In the early stage of economic and trade cooperation between China and SPIC from 1998 to 2007, China's inbound tourists from SPIC and trade have grown slowly under fluctuation. From 2008 to 2017, inbound tourists 
showed slow growth in waves, while export trade showed relatively rapid growth, from US $\$ 0.909$ billion in 2008 to US $\$ 3.494$ billion in 2017 , which mainly benefited from the two terms of China-South Pacific Island Countries Economic Cooperation Forum in 2006 and 2013. SPIC countries exported logs, fish products, minerals, and energy resources to China, but the role of the Economic Cooperation Forum in export trade has a one-year lag. At this stage, inbound tourism and import trade as a whole showed fluctuating synchronized growth. This paper uses 1998-2017 data to numerically simulate the role of inbound tourists on the promotion of export trade. The driving equation is as follows:

$$
\ln V E S C=0.767 \times \ln I T S C
$$

In the formula: Adjusted $\mathrm{R}^{2}=0.565$, and the marginal elastic coefficient is 0.767 . That is to say, $1 \%$ growth of China's tourists volume inbound from SPIC will lead to $0.767 \%$ increase of bilateral trade volume, suggesting a positive correlation between the two.

(2) The relationship between China's tourists inbound from SPIC (ITSC) and import trade (VISC). Figure 4 shows an obvious synchronized trend in both rise and fall in the inbound tourism and import trade in the long-term series. From 1998 to 2012, China's tourists inbound from SPIC and import trade experienced volatile growth, but the two were basically rising and falling simultaneously. They grew faster within the period of 2009-2011. In particular, the import trade in 2011 increased by 1.89 times compared with the situation in 2008, which is mainly due to the implementation of the trade policy of the Economic Cooperation Forum in 2006 and the effect of China's assistance to 167 fund projects in SPIC countries from 2006 to 2013. In 2013, because of the tsunami, both inbound tourists and import trade fell sharply: inbound tourists dropped from 12,300 to 11,000 , and import trade dropped from US\$3.275 billion to US $\$ 2.929$ billion, with a decrease of $10.57 \%$ and $10.56 \%$ respectively. Affected by the policies of the second Economic and Trade Cooperation Forum in 2013, both inbound tourists and import trade increased rapidly from 2014 to 2016: inbound tourists increased from 11,100 in 2014 to 14,200 in 2016, and import trade also increased from US $\$ 2.688$ billion in 2014 to US $\$ 5.453$ billion in 2016, with an increase of $27.93 \%$ and $103 \%$ respectively. A lag is nevertheless evident between the trade policy and inbound tourism and import trade. In 2017, the inbound tourists remained basically unchanged, but the import trade declined by $13.34 \%$. Applying the data in 1998-2017, the numerical relationship between inbound tourists and import trade is simulated, and the driving equation is established as follows:

$$
\ln V I S C=0.740 \times \ln I T S C+0.007
$$

In the formula: Adjusted $\mathrm{R}^{2}=0.523$, and the marginal elastic coefficient is 0.740 . That is to say, $1 \%$ growth of China's tourists volume inbound from SPIC will lead to $0.740 \%$ increase of bilateral trade volume, suggesting a positive correlation between the two.

(3) The relationship between China's tourists inbound from SPIC (ITSC) and bilateral trade (IE). Analyzing the correlation between the import and export trade volume and China's tourists inbound from SPIC, the driving equation of inbound tourists and the import and export trade is as follows: 


$$
\ln I E=0.765 \times \ln I T S C
$$

In the formula: Adjusted $\mathrm{R}^{2}=0.562$, and the marginal elastic coefficient is 0.765 . That is to say, $1 \%$ growth of China's tourists volume inbound from SPIC will lead to $0.765 \%$ increase of bilateral trade volume, suggesting a positive correlation between the two.

From equations (8)-(10) and Figures $3 \& 4$, it is evident that there are great differences between the various stages of the interaction between inbound tourism and trade. In the early stage, inbound tourism has a weak driving effect on bilateral trade, which is mainly affected by bilateral policies and the instability of economic cooperation, and the effect of business tourists on trade has a significant lag. From a horizontal comparison, the promotion effect of inbound tourism on export trade is more than that on import trade. The regression analysis of the three equations shows weaker explanatory power and weaker driving effect.

\section{Relationship between tourism interaction and trade dependence}

\section{Analysis of the Chinese perspective}

Figure 5 shows the growth trend of SPIC inbound Chinese tourists to China inbound tourists (SCIT) and China's dependence on SPIC (CTS) from 1998 to 2017. For 20 years, SCIT and CTS had a tortuous development. CTS was more volatile than SCIT, indicating that CTS is more affected than SCIT by major events. Figure 5 shows that: in the 20 years investigated, there were negligible changes in SPIC inbound Chinese tourists to China inbound passenger tourists (SCIT), ranging between $0.010 \%$ and $0.013 \%$. This was mainly because the number of tourists entering SPIC was low, reaching 14, 000 in 2017. This is negligible compared with the huge number of people inbound China. This result also shows that the Chinese government must accelerate cultural and educational exchanges with SPIC residents.

China's dependence on SPIC trade reflects strong temporal characteristics. In 1998, due to the financial crisis, China's trade with SPIC dropped significantly, and China's dependence on SPIC (CTS) was just $0.008 \%$. Two peaks were reached in 2007 and 2013, mainly due to the presence of the Chinese Premier Wen Jiabao at the China-South Pacific Island Countries Economic Development Cooperation Forums held in Fiji in April 2006 and in Guangzhou in November 2013, which promoted trade and inbound tourism between China and the Pacific. These same two years (2007 and 2013) were also the largest two-year periods for China's import and export trade in SPIC. This shows that centralized procurement in forums and exhibitions between China and SPIC entails a development of bilateral trade and is a good way of facilitating mutual understanding among partners.

In order to explore the influence mechanism of major events, this paper established a major events (ME) regulation model for SCIT and CTS. The data from 1998 to 2017 was used for regression and adjustment analysis using OLS method. The correlation driving equation was established as follows:

$$
\ln C T S=-0.2926+0.206 \ln S C I T+2.4039 \ln M E+0.8491 \ln M E * \ln S C I T
$$

In the formula, Adjusted $\mathrm{R}^{2}=0.7382$; Moderator item $\Delta \mathrm{R}^{2}=0.2676, \mathrm{P}<0.01$. The results show that major events have a moderating effect on the proportion of SPIC tourists and trade 
dependence on SPIC. That is, the coefficient of SCIT on CTS increases by $0.8491 \%$ for every $1 \%$ increase of major events, indicating that major events have a promoting effect on the proportion of inbound tourism and trade dependence.

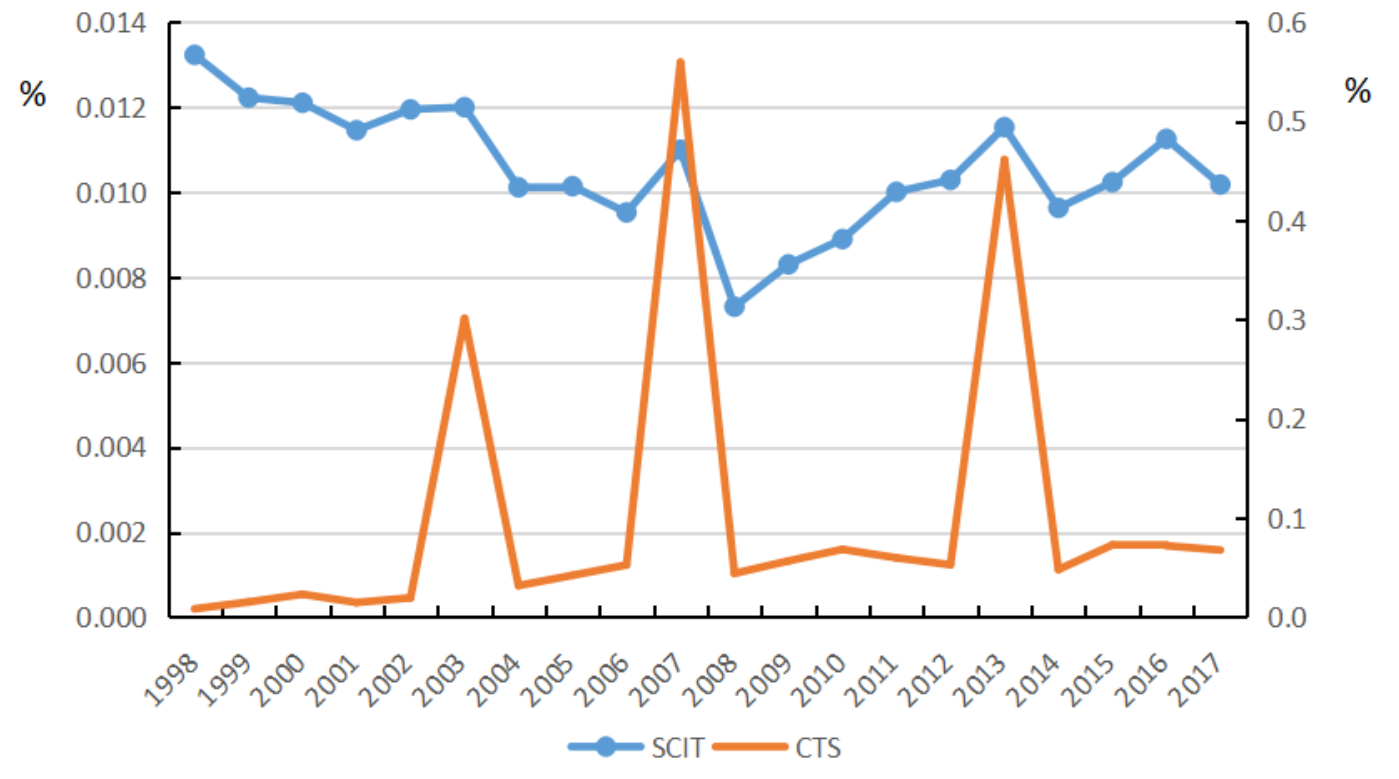

Figure 5. SCIT and CTS growth trend chart.

\section{Analysis of SPIC perspective}

As can be seen from Figure 6, in the 20 years investigated the ratio of China's outbound SPIC tourists (CSIT) and SPIC's dependence on China's trade (STC) have shown an upward trend. This indicates that Chinese tourists to SPIC have increased on a yearly basis, and their proportion has also increased, reaching a peak of $7.81 \%$ by 2015 . SPIC have also been increasingly dependent on China's trade, with a peak of $30.24 \%$ in 2015 . This mainly depends on the late development of China's outbound tourism in the South Pacific region. After 1998, with the improvement of China's international status, the South Pacific region has attracted the attention of the Chinese government. More countries have established diplomatic ties, human exchanges have gradually increased, and China's affordable goods have attracted the attention of SPIC. The interaction between tourism and trade over the past 20 years can be divided into two stages. During the first stage, from 1998 to 2008, the ratio of China's outbound SPIC tourists (CSIT) decreased, but SPIC's dependence on China's trade (STC) increased. The growth of the two was uncoordinated and unbalanced state, indicating that tourism trade accounted for a relatively small proportion of import and export trade and did not affect bilateral trade, which consists mainly of bulk commodities. In the second phase, from 2009 to 2017, the proportion of tourists and trade dependence increased, and while CSIT continued to rise, STC increased in volatility. However, tourism trade in 2009-2014 still represented a small proportion of the total import and export trade. After 2014, it continued to grow, and both CSIT and STC followed identical increase and decrease trends. As can be seen from the above comparative analysis, the ratio of Chinese inbound SPIC tourists to inbound SPIC and the degree of SPIC trade dependence on China differ from each other due to disturbance and fluctuation. On the whole, however, they show a very significant increase of synchronicity and correlation. In this paper, data from 1998 to 2017 
was used for regression analysis of CSIT and STC by OLS method, and the correlation driving equation was established as follows:

$$
\ln S T C=0.614 \ln C S I T
$$

In the formula: Adjusted $\mathrm{R}^{2}=0.5172$, the marginal coefficient of elasticity is 0.614 . In other words, for every $1 \%$ increase in the proportion of Chinese outbound SPIC tourists, SPIC's trade dependence on China will increase by $0.614 \%$.

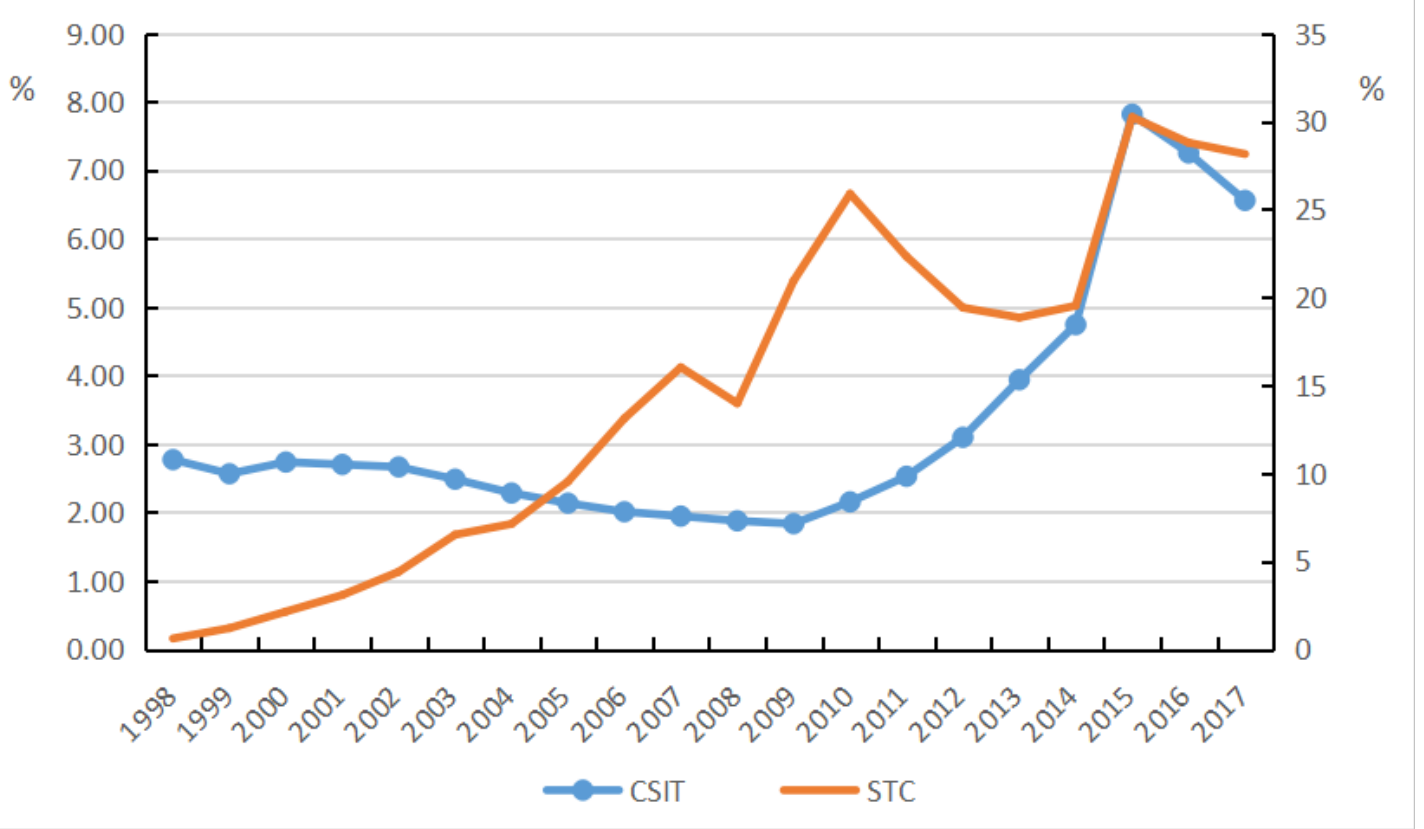

Figure 6. CSIT and STC growth trend chart.

\section{Conclusions}

International tourism and international trade are interrelated dynamic feedback loops. Tourism promotes trade, trade promotes tourism, and the two-way interaction between the two has become a linkage system that promotes continual growth of international tourism and international trade (Zhao et al, 2011). Taking China and SPIC as research objects, this paper applies the inbound and outbound tourists and the import and export trade volume in the period of 1998-2017 to analyze the equilibrium state of tourism and trade interaction and causality, draws tendency diagrams from the perspectives of China and SPIC, and establishes correlation equations to reveal the state characteristics, causality, and strength of the interaction between China and SPIC inbound and outbound tourists and import and export trade.

The main conclusions are as follows: (1) The results of the E-G two-step co-integration test have shown that there is a positive long-term equilibrium relationship between South Pacific island countries and China in inbound and outbound tourists and import and export trade. (2) Granger causality test finds that, within a certain lag period, China's tourists outbound to SPIC has promoted China's import trade from SPIC, and China's export trade to SPIC has promoted China's tourists outbound to SPIC. (3) From the double logarithmic regression equations (5)-(10), it can be seen that the interactive relationship between inbound 
and outbound tourism and import and export trade under policies effect has stage characteristics, which are slow growth stage, rapid growth stage and adjustment development stage. This conclusion is confirmed by Sun's (2012) research results: in the driving effect of China's tourists volume outbound to SPIC on trade, import trade is stronger than export trade. For every 1\% increase in China tourists outbound to SPIC, China's import trade volume from SPIC would increase by $0.924 \%$, while China's export trade volume to SPIC would only increase by $0.877 \%$. This result further explains the Granger causality test. In the driving effect of China's tourists inbound from SPIC on the trade, export trade is stronger than import trade, but both the driving force and the explanation are weaker. (4) In the two cross-sectional analyses, viewed from the perspective of China, there is volatility relation between the proportion of China tourists inbound from SPIC and China's trade dependence on SPIC. The proportion of major events has a moderating effect on SPIC tourists (SCIT) and trade dependence on SPIC (CTS). For every 1\% increase in major events, the coefficient of SCIT to CTS would increase by $0.8491 \%$. The proportion of China's tourists outbound to SPIC and the trade dependence of SPIC on China have shown an upward trend, and a $1 \%$ increase in the proportion of China's tourists outbound to SPIC would mean the trade dependence of SPIC on China would increase by $0.614 \%$.

\section{Recommendations}

In order to further promote the development of import and export trade and inbound and outbound tourism between China and SPIC, this paper recommends the following.

First, it is recommended that China seize the historic opportunity to promote the BRI and attaches great importance to the interaction between tourism and trade. China is actively developing various trade relations with SPIC, including by engaging in straightforward financial assistance through non-repayable or low-interest loans, to promote the positive development of bilateral relations (Wu \& Ye, 2017). Tourism cooperation has not only expanded the choice of Chinese outbound tourists to include island tourism but also helped promote the development of import and export trade. The two sides should carry out exchanges and cooperation in tourism product development, market docking, and route promotion in order to organize year-round tourism activities. They should furthermore launch China-SPIC regional boutique tourism routes and increase island tourism marketing efforts (Liu \& Wang, 2014). A tourism circle should be formed in both China and SPIC, gradually enhancing regional cooperation and promoting cultural integration, complementarity, and mutual exchange between China and SPIC, with the aim of ultimately achieving shared development and prosperity.

Second, it is recommended that focus be placed on the economic cooperation platform and promotion of the two-way interaction between tourism and trade. This interaction can be roughly divided into three types: tourism promotes trade, trade promotes tourism, and a mixed type (Shi, Zhou, \& Shen, 2015). It is thus necessary to adopt different trade development policies in accordance with the characteristics and bilateral needs of different countries, thereby realizing the benign interaction between tourism and trade (Chen, Cheng, \& Song, 2017). At present, China and SPIC are experiencing a mixed type of tourism-trade interaction. This heightens the importance of fully and continuously promoting trade and publicizing platforms such as the China-South Pacific Island Countries National Tourism 
Year and the China-South Pacific Island Countries Economic Development Cooperation Forum. In this way, more Chinese residents can learn about SPIC, and SPIC can promote the development of outbound tourism and enhance the two-way promotion of outbound tourism and trade. This will help ensure that the BRI's 21 ${ }^{\text {st }}$-Century Maritime Silk Road comes to benefit the island countries of the South Pacific.

Third, it is recommended that the various parties accelerate the development of interconnections and lay solid foundations for China-South Pacific tourism and trade cooperation. The two sides should aim at policy coordination, facility connectivity, barrierfree trade, capital finance, and creating inter-community bonds in order to provide good external conditions for the development of tourism and import and export trade. Significant to this should be efforts to exploit the $21^{\text {st }}$-Century Maritime Silk Road to strengthen international tourism transportation infrastructure (Lim, Zhu, \& Koo, 2019), facilitating construction of reception service facilities, gradually increasing direct flights between China and major island countries of the South Pacific, opening large cruise ships to the South Pacific countries, planning large-scale international shipping routes between China and the major SPIC, and improving transportation between China and SPIC. Improved trade customs clearance policies and visa-free tourism policies should also be introduced to establish a more balanced and sustainable trading system, promote tourism through trade, and promote trade through tourism. In addition, the two sides should accelerate communications and exchanges in fields such as culture, history, and education; enhance mutual political trust and popular support among the countries; and provide political guarantees and new sources of development for China and SPIC import and export trade.

\section{Acknowledgements}

An earlier version of the paper was presented at the 'Silk Road Archipelagos: Islands in the Belt and Road Initiative' conference, held in Fuzhou, China on 9-10 November 2019. We wish to thank the participants for their useful comments. We also thank the anonymous reviewers and Professor Gordon B. Cooke for their very useful criticisms and suggestions.

\section{References}

Cheer, J.M., Pratt, S., \& Tolkach, D. (2018). Tourism in Pacific island countries: A status quo round-up. Asia $\&$ the Pacific Policy Studies, 5(3), 442-461. https://doi.org/10.1002/app5.250

Chen, Q., \& Cheng, C. (2018). The threshold effect of trade on tourism and country differences_ — based on the empirical study of China and 24 target countries. Tourism Journal, 33(11), 40-50. http://doi.10.3969/j.issn.1002-5006.2018.11.010

Chen, Q., Cheng, C., Song, J. (2017). Research on the interaction between tourism and trade in China-ASEAN. Guangxi Social Sciences, 10, 72-77. http://doi.10.3969/j.issn.1004-6917.2017.10.014.

Hazari, B., \& Sgro, P. (2004). Tourism and trade. In B. Hazari \& P. Sgro (Eds.), Tourism, trade and national welfare (pp. 1-9). Emerald.

Katircioglu, S. (2009). Tourism, trade and growth: The case of Cyprus. Applied Economics, 41(21), 2741-2750. https://doi.10.1080/00036840701335512 
Kulendran, N., \& Wilson, K. (2002). Is there a relationship between international trade and international travel? Applied Economics, 32(8), 1001-1009. https://doi.org/10.1080/000368400322057

Lim, C., Zhu, L., \& Koo, T.T.R. (2019). Urban redevelopment and tourism growth: Relationship between tourism infrastructure and international visitor flows. Tourism Research, 21(2), 187-196. https://doi.org/10.1002/jtr.2253

Liu, J., \& Wang, G. (2014). The research on tourism cooperation between China and Pacific Island Countries. Pacific Journal, 11, 47-54. https://doi.10.3969/j.issn.1004$\underline{8049.2014 .11 .006}$

Li, Y., Chen, Y., \& Liu, (2017). Research on the interaction between tourism and trade between China and Australia. Resource Development and Market, 33(6), 721-726. https://doi.org/10.3969/j.issn.1005-8141.2017.06.015

Kumar, M., Prashar, S., \& Jana, R.K. (2019). Does international tourism spur international trade and output? Evidence from wavelet analysis. Tourism Economics, 25(1), 22-33. https://doi.org/10.1177/1354816618788392

Ma, H., \& Sun, G. (2019). An empirical research on the interaction of transportation, international tourism and trade (3T) in Hong Kong. Journal of Chongqing University of Arts and Sciences, 38(4), 35-44. https://doi.10.19493/j.cnki.issn1673-8004.2019.04.005

Massidda, C., \& Mattana, P. (2013). A SVECM analysis of the relationship between international tourism arrivals, GDP and trade in Italy. Journal of Travel Research, 52(1), 93-105. https://doi.org/10.1177/0047287512457262

Narayan, P.K., Narayan, S., Prasad, A., \& Prasad, B.C. (2010). Tourism and economic growth: A panel data analysis for Pacific Island Countries. Tourism Economics, 16(2), 169-183. https://doi.org/10.5367/000000010790872006

Narayan, P.K., Sharma, S.S., \& Bannigidadmath D. (2013). Does tourism predict macroeconomic performance in Pacific Island countries?. Economic Modelling, 33(6), 780-786. https://doi.org/10.1016/j.econmod.2013.05.018

Rasheed, R., Meo, M. S., Awan, R. U., \& Ahmed, F. (2019). The impact of tourism on deficit in balance of payments of Pakistan: An application of bounds testing approach to cointegration. Asia Pacific Journal of Tourism Research, 24(4), 325-332. https://doi.org/10.1080/10941665.2018.1564345

Santana-Gallego, M., Ledesma-Rodríguez, F., \& Pérez-Rodríguez, J.V. (2011). Tourism and trade in OECD countries. A dynamic heterogeneous panel data analysis. Empirical Economics, 41(2), 533. https://doi.org/10.1007/s00181-011-0477-9

Shan, J., \& Wilson, K. (2010). Causality between trade and tourism: empirical evidence from China. Applied Economics Letters, 8(4), 279-283. https://doi.org/10.1080/135048501750104114

Shi, Z., Zhou, Y., \& Shen, J. (2015). Interactions between inbound tourism from nine Asian countries and import and export trade. Resources Science, 37(9), 1871-1879.

Shie, T.R. (2007). Rising Chinese influence in the South Pacific: Beijing's 'island fever'. Asian Survey, 47(2), 307-326. https://doi.10.1525/as.2007.47.2.307

Siskos, E., \& Darvidou, K. (2018). Bilateral trade and tourism relations between the EU and BSEC countries. Problems and Perspectives in Management, 4, 91-101. https://doi.org/10.21511/ppm.16(4).2018.09 
Sun, G., \& Zhou, L. (2012). Research on the relationship between Japan, South Korea and ASEAN countries entering China's tourism and import and export trade. Human Geography, 6, 87-94.

Wang, J. (2012). The empirical analysis on the relationship between inbound tourism and import \& export trade. Economic Problems, 11, 99-103.

Wu, G., \& Ye, F. (2017). Regional spatial and temporal variations analysis on the economic difference in the South Pacific Islands. Marine Development and Management, 5, 33-37. https://doi.10.3969/j.issn.1005-9857.2017.05.006

$\mathrm{Xu}, \mathrm{X}$. (2018). China's cooperation with South Pacific island countries ushered in new opportunities. Chinese Academy of Social Sciences, 451, 12-14.

Ye, F., \& Wu, G. (2016). An analysis of the economic running track of South Pacific countries: Based on the data of 2004-2013. Journal of Guangdong University of Foreign Studies, 27(4), 48-57. http://doi.10.3969/j.issn.1672-0962.2016.04.007

Yin, P., Liu, S., Duan, P., \& Wang, W. (2019). Trade characteristics and its influencing factors between China and Small Island Developing States. Economic Geography, 3, 117 124. http://doi.10.15957/j.cnki.jjdl.2019.03.014

Zhao, D., Sun, G., Ma, L., \& Wang, J. (2011).China's research on the interaction between inbound and outbound tourism and import and export trade in Russian port cities: A case of Manzhouli City from 1993 to 2009. Economic Geography, 31(10), 1733-1739. 
Fang Ye et al. 